\title{
Floristic Composition and Structural Diversity of Shasha Forest Reserve in Ile-Ife, Southwestern Nigeria
}

\author{
Damilare Stephen AKINYEMI*, Samson Olajide OKE
}

Obafemi Awolowo University Ife-Ife, Department of Botany, Nigeria; sakinyemi@oauife.edu.ng(“corresponding author); soke@oauife.edu.ng

\begin{abstract}
The floristic composition and structural diversity were studied in two plots, $25 \mathrm{~m} \mathrm{x} 25 \mathrm{~m}$ each, in three different sites of varying vegetation physiognomy: Taungya system, Regrowth forest and Gmelina arborea plantation (TS, RF and GA respectively) of Shasha forest reserve in Ile- Ife southwestern Nigeria. A total of 119 plant species belonging to 51 families and 100 genera were identified in the forest reserve. Woody species represented the most diverse life form. Plant species diversity was higher in the GA ( $\left.\mathrm{H}^{\prime}=3.5\right)$ compared to the RF $\left(\mathrm{H}^{\prime}=3.4\right)$ and TS $\left(\mathrm{H}^{\prime}=2.9\right)$. Woody plant species density also differed significantly $(\mathrm{p}<0.05)$ among the different physiognomy. Mean basal area and mean girth size were higher in RF compared to TS and GA. Species evenness was also quantitatively higher in the TS (E=0.12) compared to RF (E=0.09) and GA (E=0.08). Sorensen index of similarity were 12.12\% (TS and RF), 19.71\% (TS and GA) and 20.20\% (RF and GA), which is an indication of the heterogeneity of the three different sites, as a result of different management systems of the sites. The knowledge about species composition in the forest reserve will go a long way in identifying important elements of plant diversity, protecting and preserving threatened plant species, monitoring and providing effective management of the forest reserve.

Keywords: density, flora, heterogeneity, physiognomy, structure, woody species
\end{abstract}

\section{Introduction}

Worldwide the degradation, fragmentation and conversion of forest ecosystems is progressing rapidly (Abramovitz, 1998). Globally, concerns are raised over the rapid loss of biodiversity in all its forms and at all levels. Habitat destruction is the main cause of the biodiversity loss. Habitats can either disappear completely or they may be degraded and/or fragmented, both causing serious impacts on species development, as well as lack of balance between ecosystems' processes (Raghubanshi and Tripathi, 2009). Presently, many forests persist as forest fragments and there is a growing interest in quantifying habitat characteristics such as forest structure, floristic composition and plant species richness in intact and degraded forest fragments and forest landscapes (Bierregaard et al., 1992; Myers et al., 2000). Knowledge of the floristic composition and structure of forest reserves is critical to understanding the greater dynamics of forest ecosystems and for identifying important elements of plant diversity, protecting threatened or economic species and monitoring the state of reserves, and it is with this data that management practices can be applied. The effective management of such ecosystems requires the understanding of their functioning, not only for their improvement, but also to arrest their further degradation (Oke and Isichei, 1997). Thus, the study of floristic composition and structure of tropical forest becomes more imperative in the face of ever increasing threat to the forest ecosystem.
Studies have shown that composition and structure of forests are influenced by a number of factors (Klinge et al., 1995; Haugaasen et al., 2003; Wittmann and Junk, 2003). One of these factors are disturbances which cause local species variation within forests based on their intensity, scale and frequency (Hill and Curran, 2003; Laidlaw et al., 2007). Disturbance regimes dominated by natural and anthropogenic factors may alter composition, diversity and structure of the forest. There have been massive deforestation and forest degradation of forest reserves in Nigeria as a result of human activities and inadequate or lack of effective management of the reserves. This endangers the forest reserves and the services (socio-economic and ecological) they render.

The Shasha forest reserve was one of the forest reserves established in Nigeria, generally believed to be ecologically rich and biologically abundant with forest tree species. Shasha forest reserve was originally created in 1925 and has witnessed a rapid rate of destruction from excessive logging, conversion to plantations and farming (Field Trip Earth, 2008). Deforestation is widespread, leaving no section untouched (Salami et al., 2007). For the conservation status of the Shasha forest reserve to be known and to allow effective management of the forest reserve there is a need for proper documentation of its plant species. Knowledge of the current floristic composition and structure of the Shasha forest reserve is thus invaluable. Floristic data obtained in this regard would be useful for the application of sound management practices in the forest. This study was therefore carried out to determine the composition, structure and assess the soil status of the forest reserve. 
434

\section{Materials and methods}

Study area

The study was carried out in the Shasha forest reserve in Ife south Local government Area of Osun state, southwestern Nigeria (Fig. 1). The forest reserve lies between latitude $78^{\prime}$ and $7^{\circ} 10^{\prime} \mathrm{N}$ and longitude $420^{\prime}$ and $44^{\circ} 40^{\prime} \mathrm{E}$. The study site has a land area of $310798 \mathrm{~km}^{2} / 31079.85$ ha (Salami et al., 2007). The vegetation is part of the tropical rainforest ecosystem in Southwest Nigeria. The altitude of the forest is $122 \mathrm{~m}$, with a mean annual rainfall of $1421 \mathrm{~mm}$ (Adekunle, 2006). It is an area with high relative humidity. There are two prominent seasons: dry and rainy season. The dry season lasts from November to March, while the rainy season is from April to October. The soil of the site is ferruginous tropical soil on crystalline acid rock, the topography gently undulating plain. The study was specifically carried out in three distinct study sites, namely a Taungya system (TS), cultivated site consisting of arable crops and woody species- a natural Regrowth forest (RF) and a mono-culture plantation of Gmelina arborea (GA), which were all selected from the forest reserve based on their physiognomy. The reserve has witnessed some form of disturbance such as logging and farming activities.

\section{Data collection and analysis}

The data was collected in March (dry season month). Two sample plots of $25 \mathrm{~m} \times 25 \mathrm{~m}$ in each being identified vegetation physiognomy (sites TS, RF and GA). The sites were laid out using a measuring tape and demarcated with wooden pegs for the study. In all three sites, all woody plants

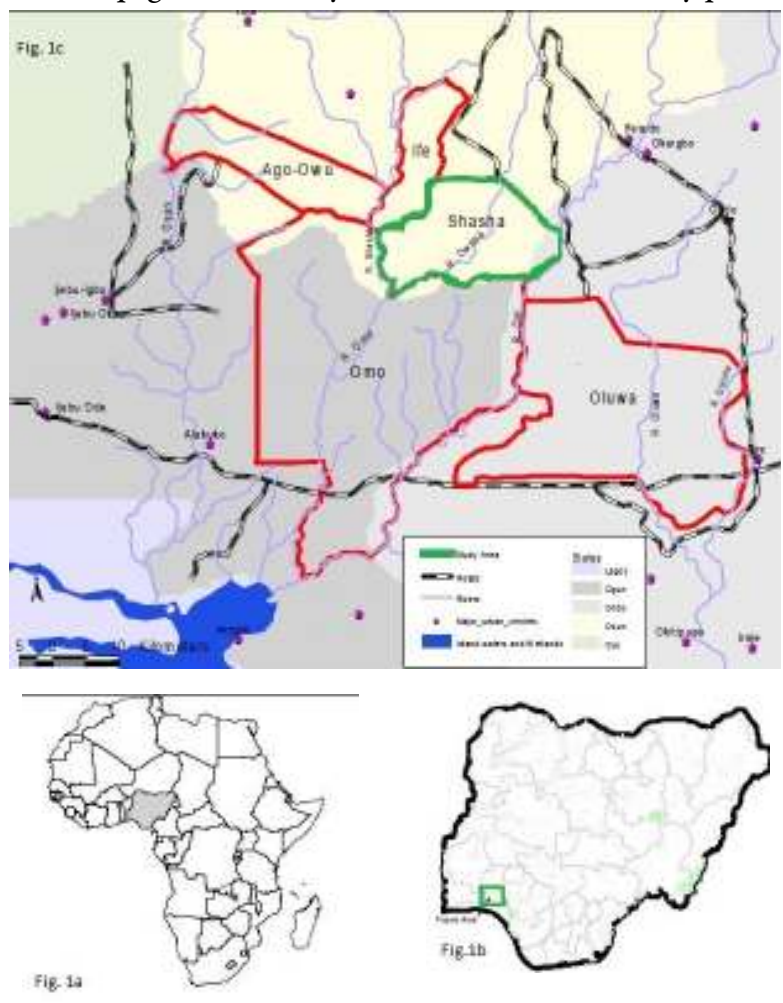

Fig. 1. Map of Africa (Fig. 1a), Nigeria (Fig. 1b) and Shasha forest reserve (Fig.1c). Adapted from Omo-Shasha-Oluwa Initiative in Protected areas that were greater than (or about) one meter in height were enumerated and identified to species level. The diameter at breast height $(\mathrm{dbh})$ of all the identified woody species was measured. The identification followed the Flora of West Africa (Hutchinson and Dalziel, 1954-1972). The species whose identities were in doubt were collected and taken to IFE herbarium where proper identification was carried out. Floristic composition, densities, diversity and distribution of the plant species were determined using the following parameters: species richness, diversity indices, Shannon Wiener index, Sorenson's index and species evenness (E).

The diversity index H' was calculated using the method prescribed by Shannon and Wiener index (1963) as:

$$
\mathrm{H}=-\sum \frac{\mathrm{n}_{1}}{\mathrm{~N}} \ln \frac{\mathrm{n}}{\mathrm{N}}
$$

$\mathrm{N}$ - Importance value for each species

$\mathrm{N}$ - Total importance values

Species evenness was calculated using Shannon's equitability

$\mathrm{E}_{\mathrm{H}}=\mathrm{H}^{\prime} / \mathrm{H}_{\max }$, $\ln S$

where $H^{\prime}$ is Shannon - Wiener index of diversity, $\mathrm{H}_{\max }=$

$S$ is the total number of species in the community.

The degree of similarity in species composition among sites was compared using Sorenson's index of similarity:

$$
\mathrm{IS}_{\mathrm{s}}=\frac{2 \mathrm{C}}{\mathrm{A}+\mathrm{B}} \times 100
$$

Where $\mathrm{C}$ is the species occurring in both communities under consideration.

$A$ - Number of species occurring in plot $A$.

$\mathrm{B}-$ Number of species occurring in plot B.

The Sorenson index of similarity $\left(\mathrm{IS}_{\mathrm{s}}\right)$ was calculated for each pair wise plot comparison (Blanc et al., 2000) and this was used to generate a dendrogram showing floristic similarities.

\section{Results and discussion}

\section{Floristic composition}

A total of 119 plant species were identified in the three selected sites in the Shasha forest reserve. These belonged to 51 families and 100 genera (Tab. 1). Euphorbiaceae, Moraceae, Papilonaceae and Rubiaceae were the overall diverse families (in terms of species richness) of the adult species, contributing $28.5 \%$ of all the species in the study (Fig. $2)$. Trees $(39.5 \%)$ were the most dominant life forms, followed by herbs $(22.7 \%)$, shrubs $(21.8 \%)$ climbers $(12.6 \%)$ and grasses (3.4\%) (Fig. 3). Euphorbiaceae and Moraceae were the most diverse families in the TS, whereas Euphorbiaceae and Rubiaceae constituted the most diverse families in RF. The most important family in GA was Rubiaceae (Fig. 4). Generally, 26 woody species were encountered in TS, 41 woody species in RF and 42 woody species in GA. Woody species common to the three sites include Deinbollia pinnata, Ficus exasperata, Milicia excelsa, Rauvolfia vomitora, Rinorea dentata and Terminalia superba. 
Tab. 1. List of plant species encountered in the three study sites in Shasha forest reserve

\begin{tabular}{|c|c|c|c|c|c|}
\hline $\mathrm{S} / \mathrm{N}$ & Woody species & Family & $\mathrm{S} / \mathrm{N}$ & Woody species & Family \\
\hline 1 & Albizia zygia & Mimosaceae & 62 & Spondias mombin & Anacardiaceae \\
\hline 2 & Alchornea cordifolia & Euphorbiaceae & 63 & Sterculia rbinopetala & Sterculiaceae \\
\hline 3 & Alstonia boonei & Apocynaceae & 64 & Sterculia trigancantha & Sterculiaceae \\
\hline 4 & Allanblackia floribunda & Guttifereae & 65 & Tectona grandis & Verbanaceae \\
\hline 5 & Allophylus africanus & Sapindaceae & 66 & Terminalia ivorensis & Combretaceae \\
\hline 6 & Amphimas pterocarpoides & Ceasalpinaceae & 67 & Terminalia superba & Combretaceae \\
\hline 7 & Anglocalyx zenkeri & Papilionaceae & 68 & Trema guinensis & Ulmaceae \\
\hline 8 & Anthocleista djalonensis & Loganiaceae & 69 & Trichilia prieureana & Meliaceae \\
\hline 9 & Anthonotha macrophylla & Caesalpinaceae & 70 & Triplochiton scleroxylon & Sterculiaceae \\
\hline 10 & Antiaris africana & Moraceae & 71 & Vernonia amygdalina & Asteraceae \\
\hline 11 & Baphia nitida & Papilionaceae & 72 & Voacanga africana & Apocynaceae \\
\hline 12 & Blighia unijugata & Sapindaceae & 73 & Xylopia spp & Annonaceae \\
\hline 13 & Bridelia ferruginea & Euphorbiaceae & & FORBS & \\
\hline 14 & Bridelia micrantha & Euphorbiaceae & 1 & Asytasia gangetica & Acanthaceae \\
\hline 15 & Bulchozia coriacea & Capparidaceae & 2 & Carica papaya & Cariaceae \\
\hline 16 & Ceiba pentandra & Bombacaceae & 3 & Chromolaena odorata & Asteraceae \\
\hline 17 & Celtis mildbraedi & Ulmaceae & 4 & Corchorus aestuans & Tiliaceae \\
\hline 18 & Celtis zenkeri & Ulmaceae & 5 & Costus afer & Custaceae \\
\hline 19 & Chassalia kolly & Rubiaceae & 6 & Culcasia scandens & Araceae \\
\hline 20 & Clausena anisata & Rutaceae & 7 & Culcasia saxatilis & Araceae \\
\hline 21 & Cleistopholispatens & Annonaceae & 8 & Cyanastrum cordifolium & Tecophiliaceae \\
\hline 22 & Cnestis ferruginea & Connaraceae & 9 & Cyathula postrata & Amaranthaceae \\
\hline 23 & Cola gigantea & Sterculiaceae & 10 & Cyathula spp & Amaranthaceae \\
\hline 24 & Deinbollia pinnata & Sapindaceae & 11 & Euphorbia heterophylla & Euphorbiaceae \\
\hline 25 & Dictyandra spp & Rubiaceae & 12 & Euphorbia hirta & Euphorbiaceae \\
\hline 26 & Diospyros mobuttensis & Ebenaceae & 13 & Geophylla obvellata & Rubiaceae \\
\hline 27 & Entandrophragma angolense & Melanaceae & 14 & Ipomea hederifolia & Convolvulaceae \\
\hline 28 & Fagara macrophylla & Rutaceae & 15 & Ipomea spp & Convolvulaceae \\
\hline 29 & Ficus exasperata & Moraceae & 16 & Musa nana & Musaceae \\
\hline 30 & Ficus muсиso & Moraceae & 17 & Musa sapientum & Musaceae \\
\hline 31 & Funtumia elastica & Apocynaceae & 18 & Palisota ambigua & Commelinaceae \\
\hline 32 & Glyphea brevis & Tiliaceae & 19 & Palisota manii & Commelinaceae \\
\hline 33 & Gmelina arborea & Verbanaceae & 20 & Pauridantha birtella & Rubiaceae \\
\hline 34 & Homalium alymeri & Simaroubaceae & 21 & Phyllanthus amarus & Euphorbiaceae \\
\hline 35 & Icacina tricantha & Icacinaceae & 22 & Piper umbellatum & Piperaceae \\
\hline 36 & Jatropha gossypifolia & Euphorbiaceae & 23 & Psychotria dorothy & Rubiaceae \\
\hline 37 & Keetia vulgare & Rubiaceae & 24 & Sida corymbosa & Malvaceae \\
\hline 38 & Lecaniodiscus cupanoides & Sapindaceae & 25 & Sida acuta & Malvaceae \\
\hline 39 & Lonchocarpus cyanescens & Papilionaceae & 26 & Synedrela nodiflora & Asteraceae \\
\hline 40 & Macaranga barterii & Euphorbiaceae & 27 & Xanthosoma mafaffa & Araceae \\
\hline 41 & Macaranga spp & Euphorbiaceae & & GRASSES & \\
\hline 42 & Magaritaria discodeus & Euphorbiaceae & 1 & Andropogon gayanus & Poaceae \\
\hline 43 & Massularia macrophylla & Rubiaceae & 2 & Eragrostis spp & Poaceae \\
\hline 44 & Microdesmis puberula & Pandaceae & 3 & Oplismenus burmanii & Poaceae \\
\hline 45 & Milicia excelsa & Moraceae & 4 & Setaria barbata & Poaceae \\
\hline 46 & Monodora tennuifolia & Annonaceae & & CLIMBERS & \\
\hline 47 & Morinda lucida & Rubiaceae & 1 & Acacia ataxacantha & Mimosaceae \\
\hline 48 & Musanga cercropoides & Moraceae & 2 & Calopogonium mucunoides & Papilionaceae \\
\hline 49 & Myrianthus arboreus & Moraceae & 3 & Cissus spp & Vitaceae \\
\hline 50 & Oxyanthus spp & Rubiaceae & 4 & Combretum spp & Combretaceae \\
\hline 51 & Pycnanthus angolensis & Myristicaceae & 5 & Culcasia scandens(creeper) & Araceae \\
\hline 52 & Rauvolfia vomitoria & Apocynaceae & 6 & Dioscorea bulbifera & Dioscoraceae \\
\hline 53 & Rinorea dentata & Violaceae & 7 & Dioscreophyllum cumminsi & Menispermaceae \\
\hline 54 & Rinorea welwiltchii & Violaceae & 8 & Dioscorea dumentorum & Dioscoraceae \\
\hline 55 & Rothmania whitfiedii & Rubiaceae & 9 & Dioscorea spp & Dioscoraceae \\
\hline 56 & Sabicea africana & Rubiaceae & 10 & Momordica charantia & Cucurbitaceae \\
\hline 57 & Salacia pallescens & Celastraceae & 11 & Mondia whitei & Periplocaceae \\
\hline 58 & Senna birsuta & Ceasalpinaceae & 12 & Passiflora foetida (creeper) & Passifloraceae \\
\hline 59 & Senna occidentalis & Caesalpinaceae & 13 & Piperguineense & Piperaceae \\
\hline 60 & Solanum verbascifolium & Solanaceae & 14 & Sabicea calycina & Rubiaceae \\
\hline 61 & Sphenonocentrum jollyanum & Menispermaceae & 15 & Vigna gracillis & Papilionaceae \\
\hline
\end{tabular}


436

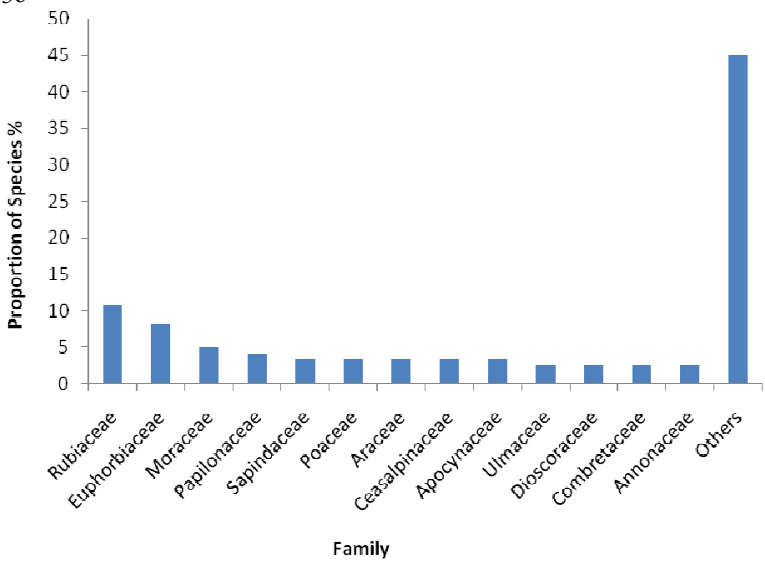

Fig. 2. Family dominance of plant species in the three study sites in Shasha Forest reserve

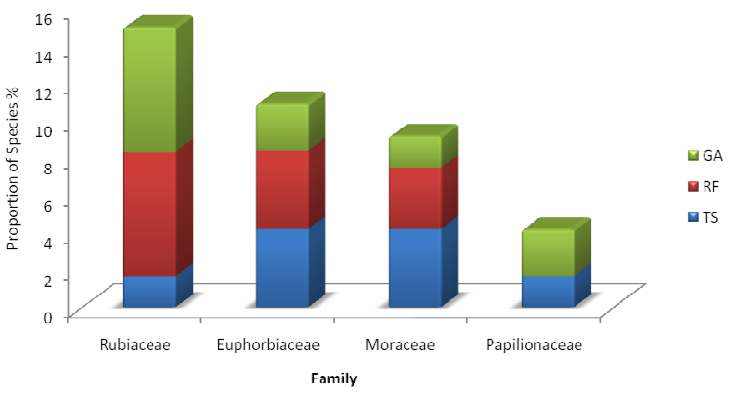

Fig. 4. Dominance of the top five families based on species richness in the respective forest sites

More herbaceous species were recorded in TS (14) than in the GA (12) and RF (7) sites, whereas climber species richness was greater in the GA (8) in relation to the other vegetation physiognomy TS (7) and RF (4). The herbaceous species common to the three sites is Chromolaena odorata. Some of the climber species observed in the three sites includes Acacia atazacantha, Cissus spp and Combretum spp. Grass species were absent in RF, but present in both TS and GS and these include Andropogon gayanus, Eragrostis spp, Oplismenus burmanii and Setaria barbata. Similarity levels were depicted in a dendrogram (Fig. 5). Some plots from different forest types were floristically different. TS1 was floristically different from other plots. TS2 and GA2 were more similar to each other, more than GA1 and RF2, while RF1 was more similar to TS2 and GA2, more than RF2 and GA.

\section{Structure}

There were a total of 2628/ha individuals of woody species (excluding other life forms) identified in the three different physiognomies. Woody species density was highest in GA (1192/ha) followed by RF (1092/ha) and least in TS (344/ha) (Tab. 2). Shannon-Wiener index was higher in the GA $\left(\mathrm{H}^{\prime}=3.5\right)$ compared to the RF $\left(\mathrm{H}^{\prime}=3.4\right)$ and TS $\left(\mathrm{H}^{\prime}=2.9\right)$ (Tab. 3). Density of woody species differed significantly between the forest types $(\mathrm{p}<0.05)$. In all, Gmelina arborea and Terminalia. superba were the most

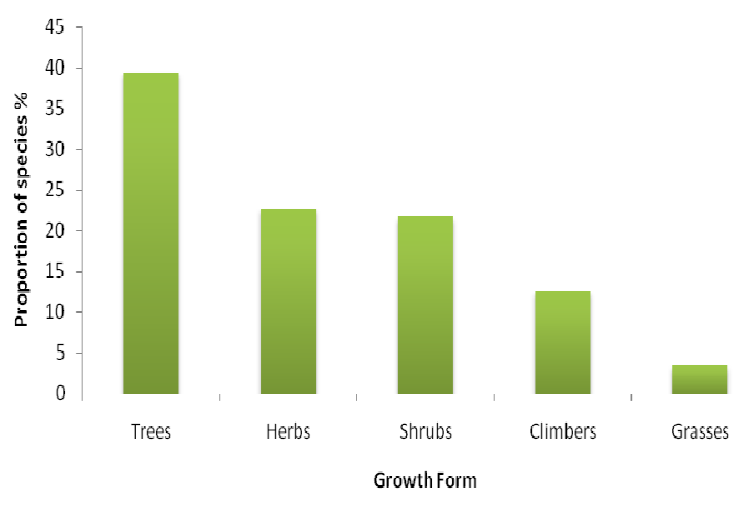

Fig. 3. Composition of plant species in the various life forms identified in the study sites in Shasha forest reserve

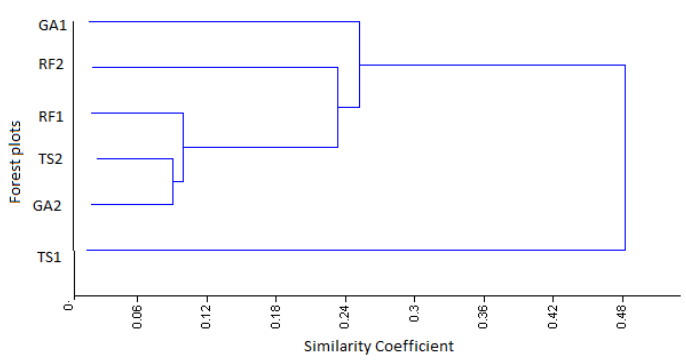

Fig. 5. Dendrogram constructed from similarity Sorenson Index matrix based on species composition in the various plots within the site

abundant species accounting for an average 26\% and $10 \%$ respectively of stems in all the three sites. In terms of basal area, Alchornea cordifolia had the highest basal area in TS, contributing with $33 \%$ of the total, in RF Alstonia boonei had the highest values contributing $65 \%$ of the total, while in GA Gmelina arborea had the highest basal area contributing $35 \%$ of the total.

On physiognomy basis, Celtis zenkeri, Ficus exasperata, Gmelina arborea and Spondias mombin were the dominant species in the TS (Tab. 2). In the case of RF, Ficus exasperata, Rauvolfia vomitora, Senna hirsuta, Terminalia superba and Trichilia prieureana were the dominant species. In GA, Blighia unijugata, Chassalia kolly, Funtumia elastica, Gmelina arborea and Rauvolfia vomitora were the species that dominated the woody flora.

In terms of size, majority of the trees were of the smaller diameter class $(0-20 \mathrm{~cm})$ (Fig. 4). The number of individual trees in the categories decreased with increasing size of the trees. Larger diameter trees $(<100 \mathrm{~cm})$ were very low in TS and GA, but not found in RF. Mean basal area recorded in the RF $\left(5.8 \pm 2.1 \mathrm{~m}^{2} / \mathrm{ha}\right)$ was higher compared with that of GA $\left(2.5 \pm 0.2 \mathrm{~m}^{2} / \mathrm{ha}\right)$ and TS $\left(0.1 \pm 0.05 \mathrm{~m}^{2} / \mathrm{ha}\right)$. The result of species evenness showed that evenness was quantitatively higher in TS $(\mathrm{E}=0.1)$ compared with $\mathrm{RF}(\mathrm{E}=0.07)$ and $\mathrm{GA}$ $(\mathrm{E}=0.08)($ Tab. 3). 
Tab. 2. Mean density of woody species (per hectare) in the three sites of the Shasha forest reserve

\begin{tabular}{|c|c|c|c|c|c|}
\hline S/N & Species & Family & TS & $\mathrm{RF}$ & GA \\
\hline 1 & Albizia zygia & Mimosaceae & & 24 & 24 \\
\hline 2 & Alchornea cordifolia & Euphorbiaceae & 8 & & \\
\hline 3 & Alstonia boonei & Apocynaceae & & 16 & 16 \\
\hline 4 & Allanblackia floribunda & Guttifereae & 16 & & \\
\hline 5 & Allophylus africanus & Sapindaceae & & 32 & \\
\hline 6 & Amphimas pterocarpoides & Ceasalpinaceae & 8 & & 16 \\
\hline 7 & Anglocalyx zenkeri & Papilonaceae & & & 16 \\
\hline 8 & Anthocleista djalonensis & Loganiaceae & & & 8 \\
\hline 9 & Anthonotha macrophylla & Caesalpinaceae & & 32 & \\
\hline 10 & Antiaris africana & Moraceae & 8 & & 16 \\
\hline 11 & Baphia nitida & Papilonaceae & 16 & & \\
\hline 12 & Blighia unijugata & Sapindaceae & & & $40 \pm 8$ \\
\hline 13 & Bridelia ferruginea & Euphorbiaceae & & 8 & 8 \\
\hline 14 & Bridelia micrantha & Euphorbiaceae & & 24 & \\
\hline 15 & Bulchozia coriacea & Capparidaceae & & 32 & 24 \\
\hline 16 & Ceiba pentandra & Bombacaceae & & & 32 \\
\hline 17 & Celtis mildbraedi & Ulmaceae & & 8 & 16 \\
\hline 18 & Celtis zenkeri & Ulmaceae & $24 \pm 8$ & 24 & \\
\hline 19 & Chassalia kolly & Rubiaceae & 8 & 8 & 48 \\
\hline 20 & Clausena anisata & Rutaceae & & & 16 \\
\hline 21 & Cleistopholis patens & Annonaceae & & & 32 \\
\hline 22 & Cnestisferruginea & Connaraceae & 8 & & 8 \\
\hline 23 & Cola gigantea & Sterculiaceae & & 16 & 24 \\
\hline 24 & Deinbollia pinnata & Sapindaceae & 16 & 24 & 16 \\
\hline 25 & Dictyandra spp & Rubiaceae & & 24 & \\
\hline 26 & Diospyros mobuttensis & Ebenaceae & 8 & & \\
\hline 27 & Entandrophragma angolense & Melanaceae & 8 & & \\
\hline 28 & Fagara macrophylla & Rutaceae & & 16 & \\
\hline 29 & Ficus exasperata & Moraceae & $32 \pm 16$ & $40 \pm 8$ & $24 \pm 8$ \\
\hline 30 & Ficus mucuso & Moraceae & 8 & & \\
\hline 31 & Funtumia elastica & Apocynaceae & & 80 & $32 \pm 16$ \\
\hline 32 & Glyphea brevis & Tiliaceae & 8 & & 24 \\
\hline 33 & Gmelina arborea & Verbanaceae & 32 & & $320 \pm 8$ \\
\hline 34 & Homalium alymeri & Simaroubaceae & & 8 & \\
\hline 35 & Icacina tricantha & Icacinaceae & & & 8 \\
\hline 36 & Jatropha gossypifolia & Euphorbiaceae & 8 & 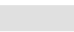 & \\
\hline 37 & Keetia vulgare & Rubiaceae & & 8 & 24 \\
\hline 38 & Lecaniodiscus cupanoides & Sapindaceae & & 8 & \\
\hline 39 & Lonchocarpus cyanescens & Papillonaceae & & & $32 \pm 16$ \\
\hline 40 & Macaranga barterii & Euphorbiaceae & & $40 \pm 8$ & 16 \\
\hline 41 & Macaranga spp & Euphorbiaceae & & 8 & \\
\hline 42 & Magaritaria discodeus & Euphorbiaceae & & 16 & 16 \\
\hline 43 & Massularia macrophylla & Rubiaceae & & & 24 \\
\hline 44 & Microdesmis pubeurla & Pandaceae & & & 24 \\
\hline 45 & Milicia excelsa & Moraceae & 16 & $40 \pm 8$ & 8 \\
\hline 46 & Monodora tennuifolia & Annonaceae & & & 16 \\
\hline 47 & Morinda lucida & Rubiaceae & & 8 & \\
\hline 48 & Musanga cercropoides & Moraceae & & 8 & \\
\hline 49 & Myrianthus arboreus & Moraceae & 8 & 8 & \\
\hline 50 & Oxyantbus spp & Rubiaceae & & $24 \pm 8$ & \\
\hline 51 & Pycnanthus angolensis & Myristicaceae & & 32 & \\
\hline 52 & Rauvolfia vomitora & Apocynaceae & 16 & $56 \pm 8$ & 48 \\
\hline 53 & Rinorea dentata & Violaceae & 8 & $32 \pm 16$ & 24 \\
\hline 54 & Rinorea welwiltchii & Violaceae & & 32 & \\
\hline 55 & Rothmania whitfiedii & Rubiaceae & & 24 & \\
\hline 56 & Sabicea africana & Rubiaceae & & & 24 \\
\hline 57 & Salacia pallescens & Celastraceae & & 52 & $24 \pm 8$ \\
\hline 58 & Senna hirsuta & Ceasalpinaceae & & 64 & \\
\hline 59 & Senna occidentalis & Caesalpinaceae & 16 & & \\
\hline 60 & Solanum verbascifolium & Solanaceae & 16 & & \\
\hline 61 & Sphenonocentrum jollyanum & Menispermaceae & & 16 & 16 \\
\hline 62 & Spondias mombin & Anacardiaceae & 24 & & \\
\hline 63 & Sterculia rbinopetala & Sterculiaceae & & 16 & 24 \\
\hline 64 & Sterculia trigancantha & Sterculiaceae & & & $24 \pm 8$ \\
\hline 65 & Tectona grandis & Verbanaceae & & & 16 \\
\hline 66 & Terminalia ivorensis & Combretaceae & & & 16 \\
\hline 67 & Terminalia superba & Combretaceae & 8 & $104 \pm 40$ & 24 \\
\hline 68 & Trema guinensis & Ulmaceae & & & 8 \\
\hline 69 & Trichilia prieureana & Meliaceae & & 56 & \\
\hline 70 & Triplochiton scleroxylon & Sterculiaceae & 8 & & 24 \\
\hline 71 & Vernonia amygdalina & Asteraceae & 8 & & \\
\hline 72 & Voacanga a fricana & Apocynaceae & & 16 & 16 \\
\hline \multirow[t]{2}{*}{73} & Xylopia spp & Annonaceae & & 8 & \\
\hline & TOTAL & & 344 & 1092 & \\
\hline
\end{tabular}

TS - Taungya system

RF - Regrowth forest

GA - Gmelina arborea plantation 
438

Tab. 3. Summary characteristics of floristic composition and structure of the Shasha forest reserve

\begin{tabular}{|c|c|c|c|c|}
\hline $\mathrm{S} / \mathrm{N}$ & Characteristics & TS & RF & GA \\
\hline 1 & Number of Families & 32 & 33 & 41 \\
\hline 2 & Number of woody species & 26 & 41 & 42 \\
\hline 3 & Number of trees & 19 & 30 & 29 \\
\hline 4 & Number of shrubs & 7 & 11 & 13 \\
\hline 5 & Number of herbs & 14 & 7 & 12 \\
\hline 6 & Number of climbers & 7 & 4 & 8 \\
\hline 7 & Density of trees ha ${ }^{-1}$ & $272 \pm 24$ & $752 \pm 40$ & $896 \pm 48$ \\
\hline 8 & Density of woody species ha ${ }^{-1}$ & $344 \pm 24$ & $1092 \pm 96$ & $1192 \pm 72$ \\
\hline 9 & Basal area $\mathrm{m}^{2} \mathrm{ha}^{-1}$ & $0.06791 \pm 0.0491$ & $5.7931 \pm 2.1081$ & $2.4872 \pm 0.1848$ \\
\hline 10 & Mean girth size $(\mathrm{cm})$ & $25 \pm 4.0$ & $35 \pm 5.0$ & $32 \pm 6.0$ \\
\hline 11 & Shannon wiener $\mathrm{H}^{\prime}$ & 2.9 & 3.4 & 3.5 \\
\hline 12 & Species evenness & 0.12 & 0.09 & 0.08 \\
\hline
\end{tabular}

TS - Taungya system

RF - Regrowth forest

GA - Gmelina arborea plantation

\section{Discussion}

Studies on floristic composition and structure in forests are instrumental in the sustainability of forest since they play a major role in the conservation of plant species and the management of forest ecosystems as a whole (Mohandass et al., 2009; Tilman, 1988; Ssegawa and Nkuutu, 2006). The results of this study show that the floristic composition of Shasha forest reserve (119 species/ha) were higher than many other tropical forests. For instance, Addo- Fordjour et al. (2009) recorded a much lower species richness (48 species/ha) in a moist semi-deciduous forest in Ghana, Mohandas and Priya (2009) recorded 86 species in a tropical montane evergreen forest in India. On the other hand, Gustav et al. (2001) recorded a much higher species richness of 208 species in the tropical wet lowland of Amazon forest, Parthasarathy (2001) recorded 125 species in a tropical wet evergreen forest in Sengaltheri of the Western Ghats in India. The species composition of the forest reserve might have been affected of the various human disturbances, such as slash and burn agriculture, felling of mature trees for timber, collection of fuel wood and other non-timber forest products, which has led to species attrition, thus leaving behind a less balanced structure.

The density of the woody and herbaceous species varied considerably in the different sites under consideration. There were more herbaceous species in TS than all other sites; this might be an indicator of the type of anthropogenic disturbances (slash and burn agriculture) in TS, facts which might favour the growth of herbaceous species. Mishra et al. (2008) observed greater diversity of herbs in disturbed forest than in undisturbed ones. There were more woody species in GA than RF; this observation could be as a result of the presence of woody species and tree saplings in the under storey of the plantation. Studies from around the world have shown that single- species plantations are at the stand scale, often less diverse than natural or semi-natural forests with respect to plants (Aubin et al., 2008). Nevertheless, it has been shown that forest plantations can contribute to restoring some of the floristic diversity on abandoned agriculture land (Newmaster et al., 2006; Aubin et al., 2008) and some plantations may have a surprisingly diverse understory (Allen et al., 1995; Keenan et al., 1997; Oberhauser, 1997) as observed in this study. This is in agreement with Tripathi and Bajrang (2009) who observed that species richness at ground layer was higher in forest plantation than in natural re-growth forest. It has been observed that pure stands (i.e. deciduous or coniferous) could support, in some cases, a richer understory vegetation than mixed- species stands and that species richness was generally greater in deciduous stands than in coniferous stands (Barbier et al., 2008). Furthermore, some conifer plantations may have greater plant species richness than broad- leaved secondary forests (Nagaike, 2002).

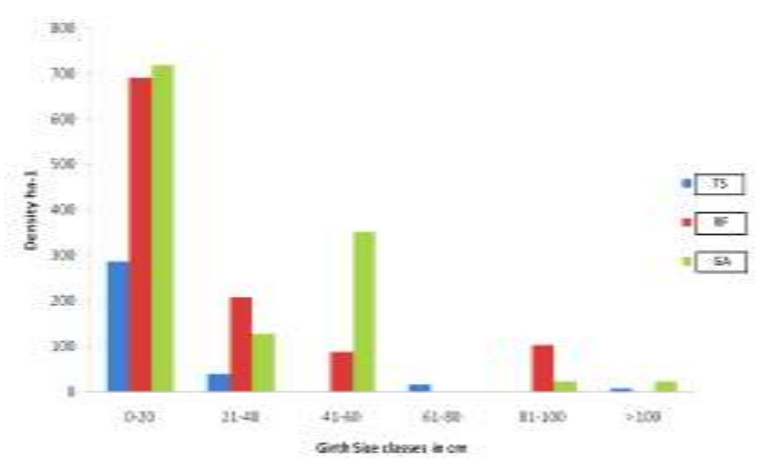

Fig. 5. Girth size distribution of trees

Grass species were present in both TS and GA, but not in RF. This observation could be as a result of open canopy in the plantations versus closed canopy in Regrowth forest. The observations in this study regarding the re-growth forest is in agreement with the results of White (1985) who noted that in a forest the ground layer is often sparse or absent, as grasses are absent or if present are localized or inconspicuous. The low similarity index observed among the three study sites is an indication of the heterogeneity in species composition in the standing vegetation of the three sites. Species similarity indices were $12.12 \%$ (TS and RF), 19.71\% (TS and GA) and $20.20 \%$ (RF and GA). Similarity index showed that similarity is highest between Regrowth forest and Gmelina arborea plantation and lowest between Taungya system and Regrowth forest. This may be due to the different system of management in the three sites. TS is a vegetation of tree species and arable crop species, while RF is a natural regrowth forest and GA is a mono - culture plantation of Gmelina arborea. Shannon-Wiener diversity index $\left(\mathrm{H}^{\prime}\right)$ followed the order Gmelina arborea > Regrowth forest > 
Taungya system. The $\mathrm{H}^{\prime}$ of $3.34-3.66$ for some rainforest sites in Nigeria (Adekunle, 2006) is similar to that of RF and GA, but higher than that of TS. The high species diversity of RF (3.47) and GA (3.49) is a reflection of the presence of high number of species found in these sites. Our results revealed that species evenness was low in all the three study sites. This might be due to the different disturbance in form of human activities such as slash and burn agriculture and gathering of wood for fuel in TS, logging in RF and GA where certain species are preferred than others. In rainforests from India, tree species richness decreased with the increase in intensity of forest disturbance (Nath et al., 2005).

Tree size class distribution can be used as indicators of changes in population structure and species composition (Newbery and Gartlan, 1996). The distribution of the girth size class has shown that TS, RF and GA were characterized by small and young tree species whose girths were mostly 0-20 $\mathrm{cm}, 21-40 \mathrm{~cm}$ and $41-60 \mathrm{~cm}$. Most species in the study plots followed reverse J-shaped distribution with greater number of individuals in small size classes. Such a trend has also been reported in the forests of Great Andaman groups (Padalia et al., 2004). This might be as a result of selective felling and logging of higher girth size classes' trees, hence most of the tree species are secondary forest re-growth species. It also indicates that the forest sites are disturbed and they are in their early successional stages. Moreover, the basal area of the woody species $\left(8 \times 10^{-6}-4.5524 \mathrm{~m}^{2}\right)$ further shows that the sites were characterized by recovery from disturbance. The general small basal area of most species, respectively small girth size, is an evidence of disturbance and degradation in the three study sites of Shasha forest reserve.

\section{Conclusion}

The study revealed that Shasha forest reserve has a reasonably good tree and shrub species composition and richness in the face of logging and slash and burn agriculture in the forest. Anthropogenic disturbances have affected the floristic composition of the forest reserve to an extent. Logging affected the structural composition of the forest reserve through the removal of large and tall trees. Thus, there is need to control human activities in the forest reserve so as to protect the plant species for effective management and utilization.

\section{References}

Abramovitz J (1998). Putting a value on Natures free services, Nature's Hidden Economy Worldwatch Institute, 11(1).

Addo-Fordjour P, Obeng S, Anning AK Addo, MG (2009). Floristic composition, structure and natural regeneration in a moist deciduous forest following anthropogenic disturbances and plant invasion. International journal of biodiversity and conservation 1(2):21-27.

Adekunle VAJ (2006). Conservation of tree species diversity in tropical rainforest ecosystem of South-west Nigeria. Journal of Tropical Forest Science 18(2):91-101.

Allen RB, Platt KH, Coker REJ (1995). Understorey species composition patterns in a Pinus radiata plantation on the central North Island Volcanic Plateau, New Zealand. New Zealand. Journal of Forestry Science 25(3):301-315.
Aubin I, Messier C, Bouchard A (2008). Can plantations develop understory biological and physical attributes of naturally regenerated forests. Journal of Biodiversity Conservation 141:2461-2476.

Barbier S, Gosselin, FS, Balandier P (2008). Influence of tree species on understory vegetation, diversity and mechanism involved a critical review for temperate and boreal forest. Forest ecology and management 254:1-15.

Bierregaard Jr RO, Lovejoy TE, Kapos V, dos Santos AA, Hutchings RW (1992). The biological dynamics of tropical rain-forest fragments. Bioscience 42:859-866.

Field Trip Earth (2008). Surveying Wildlife in Nigerian Forest.

Gustav N, Jens D, Vanclay JK (2001). Structure and floristic composition of flood plain forests in the Peruvian Amazon II. The understory of Restinga forests. Journal of Forest Ecology and Management doi: 10.1016/s03781127(00)00681-2.

Haugaasen T, Barlow J, Peres CA (2003). Surface wildfires in central Amazonia: Short-term impact on forest structure and carbon loss. For Ecol Manage 179:321-333

Hill JL, Curran PJ (2003). Area, shape and isolation of tropical forest fragments: effects on tree species diversity and implications for conservation forest area. J Biogeogr 30:1391-1403.

Hutchinson J, Dalziel JM (1954). Flora of West Tropical Africa 1(1):34-54. Keenan R, Lamb D, Woldring O, Irvine TJR (1997). Restoration of plant biodiversitybeneath tropical tree plantations in Northern Australia. Journal of Forest Ecology and Management 99:117-131.

Klinge H, Adis J, Worbes M (1995). The vegetation of a seasonal várzea in the lower Solimões river, Brazilian Amazon. Acta Amazonica 25:201-220.

Laidlaw M, Kitching R, Goodall K, Small A, Stork N (2007). Temporal and spatial variation in an Australian tropical rainforest. Austral Ecol 32:10-20.

Mishra RK, Upadhyay VP, Mohanty RC (2008). Vegetation ecology of the Similipal Biosphere Reserve, Orissa, India. Appl Ecol Env Res 6:89-99.

Mohandass D, Priya Davidar (2009). Floristic structure and diversity of a tropical and montane and evergreen forest (shola) Nilgiri mountains southern India. Tropical Ecology 50(2):219-229.

Myers N, Mittermeier RA, Mittermeier CG, da Fonseca GA, Kent J (2000). Biodiversity hotspots for conservation priorities. Nature 403:853-858.

Nagaike T (2002). Differences in plant species diversity between conifer (Larix Kaempferi) plantations and broad leaved (Quercus crispula) secondary forests in Central Japan. Forest Ecology and Management 168:111-123.

Nath PC, Arunachalam A, Khan ML, Arunachalam K, Barbhuiya AR (2005). Vegetation analysis and tree population structure of tropical wet evergreen forests in and around Namdapha National Park, Northeast India. 
440

Biodiversity and Conservation 14:2109-2136.

Newbery D, Gartlan JS (1996). A structural analysis of rain forests at Korup and Douala-Edea, Cameroon. Proceedings of Royal Society Edinburgh 104B:107-224.

Newmaster SG, Bell FW, Roosenboom CR, Cole HA, Towill WD (2006). Restoration of floral diversity through plantations on abandoned agricultural land. Can For Res 36:1218-1235.

Oberhauser U (1997). Secondary forest regeneration beneath pine (Pinus kesiya) plantations in the Northern Thai highlands: a chronosequence study. Journal Forest Ecology and Management 256:114-120.

Oke SO, Isichei AO (1997). Floristic and structure of the fallow vegetation in the Ile-Ife Area of South Western. Nigeria Journal of Botany Vol 10:30-50.

Padalia H, Chauhan N, Porwal MC, Roy PS (2004). Phytosociological observations on tree species diversity of Andaman Islands, India. Current Science 87:799-806.

Parthasarathy N (2001). Changes in forest composition and structure in three sites of tropical evergreen forest around Sengaltheri, Western Ghats Curr Sci 80:389-393.

Raghubanshi AS, Tripathi Anshuman (2009). Effect of disturbance, habitat fragmentation and alien invasive plants on floral diversity in dry tropical forests of Vindhyan highland: a review. Tropical Ecology 50(1):57-69.
Salami AT, Balogun BO, Oloyede- Kosoko SOA (2007). Geospatial data application in the assessment of population impact on a tropical lowland rainforest of Southwest Nigeria. Geo Observateur 16:31-37.

Ssegawa P, Nkuutu DN (2006). Diversity of Vascular plants on Ssese Islands in Lake Victoria Central Uganda. Afri J Ecol 44:22-29.

Tilman D (1988). Plant strategies and the dynamics and structure of plant communities. Princeton University Press. Princeton, New Jersey.

Tripathi KP, Bajrang Singh (2009). Species diversity and vegetation structure across various strata in natural and plantation forests in Katerniaghat Wildlife Sanctuary, North India. Tropical Ecology 50(1):191-200.

White PS, Pickett STA (1985). Natural disturbance and patch dynamics: an introduction, 3-13p. In Picket STA and White PS, (Eds.). The ecology of natural disturbance and patch dynamics. Academic Press, Orlando, Florida.

Wittmann F, Junk WJ (2003). Sapling communities in Amazonian whitewater forests. J Biogeogr 30:1533-1544. 